DOI https://doi.org/10.30525/978-9934-588-90-7-5

\title{
ОСОБЛИВОСТІ ПІДГОТОВКИ МАЙБУТНІХ ФІЛОЛОГІВ У КОНТЕКСТІ РЕФОРМУВАННЯ БАЗОВОЇ СЕРЕДНЬОЇ ОСВІТИ
}

\author{
Демченко Н. Д. \\ кандидат філологічних наук, дочент, \\ завідувач кафедри української лінгвістики, \\ літератури та методики навчання \\ Комунальний заклад «Харківська гуманітарно-педагогічна академія» \\ Харківської обласної ради \\ м. Харків, Україна \\ Крехно Т. I. \\ кандидат філологічних наук, доцент, \\ професор кафедри украӥнської лінгвістики, \\ літератури та методики навчання \\ Комунальний заклад «Харківська гуманітарно-педагогічна академія» \\ Харківської обласної ради \\ м. Харків, Україна \\ Чала А. Г. \\ кандидат педагогічних наук, \\ доцент кафедри української лінгвістики, \\ літератури та методики навчання \\ Комунальний заклад «Харківська гуманітарно-педагогічна академія» \\ Харківської обласної ради \\ м. Харків, Україна
}

На сьогодні українська освіта перебуває на етапі кардинальних змін і реформування. Так, 2018-2019 року було впроваджено новий Стандарт початкової освіти в усіх школах України, що передбачає зовсім інші підходи роботи вчителів початкових класів. Відповідно до Концепції «Нової української школи», в якій викладені основні засади реформи шкільної освіти та орієнтований графік іiї впровадження, учень і вчитель стають іншими, готовими приймати рішення в умовах невизначеності, орієнтованими на співпрацю, партнерами під час освітнього процесу. Ключова зміна для учнів стосується підходів до навчання та змісту освіти. Головною метою Нової української школи $\epsilon$ виховання 
інноватора та громадянина, який здатний ухвалювати відповідальні рішення, що не обмежують права інших людей [3].

Цілком логічним $\epsilon$ те, що у XXI столітті, в інформаційному суспільстві, нам вже не потрібно накопичувати знання i їх запам'ятовувати, адже вже у момент їх запам'ятовування ці знання стають застарілими. Усе це ставить перед школою завдання трансформуватися зі «школи знань» на «школу компетентностей» Так, учні мають отримувати знання й формувати навички, але не абстрактно, а набувати відповідних компетентностей, що знадобляться їм у подальшому професійному та приватному житті.

Ураховуючи вище зазначене, учитель має впроваджувати діяльнісний підхід до навчання, інтегроване та проєктне навчання, що сприятиме отриманню цілісного уявлення про світ, адже вивчення явищ дуально 3 іншими науками дає можливість навчитися вирішувати реальні проблеми за допомогою сукупності знань.

На нашу думку, найбільше відповідальність покладена на вчителя, на ньому тримається реформа, від його позиції, бажання змінюватися, від рівня його мотивації та зацікавленості залежить успіх Нової української школи. Убачаємо за необхідне враховувати це ще під час підготовки майбутніх вчителів у педагогічних закладах вищої освіти.

2022-2023 навчального року до базової середньої школи прийдуть учні, які навчалися за новим Державним стандартом початкової освіти, тому 30 вересня 2020 року Кабінетом Міністрів України був затверджений Державний стандарт базової середньої освіти, що й стало основою для реалізації реформи Нової української школи у 5-9 класах.

Стандарт не містить поділу на предмети, а лише виокремлює 9 освітніх галузей, що $є$ абсолютною інновацією для нашої середньої освіти. Наявність освітніх галузей - мовно-літературної; інформативної, соціальної й здоров'язбережувальної; громадянської та історичної; мистецької, фізичної культури - свідчить про можливість інтеграції, комбінування освітніх компонентів навчання.

Із огляду на викладене вище, убачаємо необхідним під час викладання методик окремих предметів у педагогічних закладах вищої освіти в процесі підготовки майбутніх учителів орієнтувати студентів щодо такої інтеграції вже сьогодні, адже саме їм реалізовувати у своїй майбутній роботі зазначені реформи.

За Державним стандартом базової середньої освіти виокремлено два цикли (що також є інновацією) - адаптаційний (5-6 класи) і базовий предметного навчання (7-9 класи), після закінчення яких школярі мають оволодіти ключовими компетентностями, зокрема вільне володіння державною мовою; здатність спілкуватися рідною (у разі відмінності від державної) та іноземними мовами; математична компетентність; 
компетентність у галузі природничих наук, техніки й технологій; інноваційність; екологічна компетентність; інформаційно-комунікаційна компетентність; навчання впродовж життя; громадянські та соціальні компетентності; культурна компетентність; підприємливість і фінансова грамотність [1].

Окрім цього документ містить детальний опис цих компетентностей, базові знання з кожної освітньої галузі, обов'язкові результати навчання та орієнтири щодо їх оцінювання, загальний обсяг навчального навантаження, розподіленого за освітніми галузями.

Для того, щоб учитель мав змогу навчати по-новому, він повинен отримати свободу дій - обирати навчальні матеріали, імпровізувати, експериментувати. На нашу думку саме на це націлений Закон України «Про освіту», на основі якого розроблена Концепція Нової української школи та Державний стандарт базової середньої освіти. Для вчителів будуть лише пропонуватися типові навчальні програми, проте будь-який учитель або авторська група зможе заповнювати або удосконалювати їх, єдине обмеження це відповідність Стандарту, у якому окреслено результати навчання, а шляхи їх досягання вчитель обирає сам.

На нашу думку, одночасно з реформою загальної освіти має стрімко змінюватися підготовка в педагогічних закладах вищої освіти відповідно до нових викликів сучасності.

Для підготовки філологів у педагогічному закладі вищої освіти вбачаємо край необхідною низку заходів, зокрема ознайомлення 3 нормативними документами: Концепцією Нової української школи; Законом України «Про освіту» [2], Державним стандартом початкової освіти, Державним стандартом базової середньої освіти (та врахування основних положень цих документів під час викладання професійних дисциплін); орієнтація на інтеграцію освітніх навчальних компонентів; пояснення можливості індивідуальної освітньої траєкторії учнів; націленість на навчання упродовж життя; упровадження форм і методів навчання, що забезпечуватимуть компетентнісний підхід.

Перспективною розвідкою $\epsilon$ вивчення освітніх технологій навчання мовно-літературної галузі базової середньої школи для здобувачів вищої освіти майбутніх філологів.

\section{Література:}

1. Державний стандарт базової середньої освіти [Електронний pecypc] - Режим доступу : https://www.kmu.gov.ua/npas/pro-deyaki-pitannyaderzhavnih-standartiv-povnoyi-zagalnoyi-serednoyi-osviti-i300920-898

2. Закон України «Про освіту» [Електронний ресурс] - Режим доступу : https://zakon.rada.gov.ua/laws/show/2145-19\#Text 
3. Концепція нової української школи [Електронний ресурс] Режим доступу : https://mon.gov.ua/storage/app/media/zagalna\%20 serednya/nova-ukrainska-shkola-compressed.pdf

DOI https://doi.org/10.30525/978-9934-588-90-7-6

\title{
СИЛЬНА ТА СЛАБКА СЛОВОТВІРНА НОРМА В ХУДОЖНІЙ ПРОЗІ
}

\author{
Засць В. Г. \\ кандидат педагогічних наук, \\ доиент кафедри украӥнської мови \\ Київький університет імені Бориса Грінченка \\ м. Київ, Украӥна
}

Аналізовані художні твори новітньої доби експліцитно демонструють 3 одного боку, тенденції відродження словотвірної норми, іiі відповідність чинним мовним нормам, сталість та константність літературних взірців, а з іншого - певну нестабільність, рухливість, подекуди мінливість.

В україністиці мовна практика сучасної художньої прози розглядається здебільшого у площині особливостей словотворчості окремого автора або авторів, що контекстуально втілює уміння письменника лексичними засобами передавати співіснування мови на тлі концептуальної картини світу.

Авторський текст художнього стилю незалежно від жанрової специфіки відбиває продуктивні, малопродуктивні словотвірні типи та співіснування в узусі прескриптивної та дескриптивної норм, що стали об'єктом досліджень К. Городенської, С. Єрмоленко, С. Бибик, О. Стишова, Л. Кислюк, Т. Коць та ін. [1;7].

Українська літературна мова художнього стилю в останні три десятиріччя утверджувала престиж надбання нації, об'єднувала носіїв навколо словотворчості письменників, ілюструвала особливості авторського ідіостилю.

Зокрема помічено, що в іменниковому словотворенні художньої прози новітньої доби активністю позначений словотвірний тип на позначення осіб «за місцем народження, проживання» похідними дериватами чоловічого роду з найуживанішими суфіксами -анин (-янин), -чанин, -ин, -ак (-як), на зразок: австріяк, батуринець, галичанин, 